\title{
MORZE BAŁTYCKIE W ZAŁOŻENIACH STRATEGII MORSKICH I POLITYK BEZPIECZEŃSTWA NARODOWEGO PAŃSTW BAŁTYCKICH. WNIOSKI DLA KONCEPCJI BEZPIECZEŃSTWA MORSKIEGO RP
}

\author{
Piotr Mickiewicz
}

Akademia Marynarki Wojennej

\begin{abstract}
Streszczenie. Zlewisko Morza Bałtyckiego uznawane jest za obszar stabilności politycznej, na którym niewielkie jest prawdopodobieństwo wystąpienia konfliktu zbrojnego. Nie oznacza to, że nie jest to region, w którym nie ma miejsca na rywalizację polityczno-gospodarczą, która kreuje określone zagrożenia bezpieczeństwa. Wynikają one głównie z prowadzonej przez państwa regionu polityki morskiej. Tym samym koncepcje ich niwelowania przyjmują przede wszystkim postać działań polityczno-gospodarczych, a rolą sił morskich jest w pierwszej kolejności zagwarantowanie i ochrona interesów morskich państwa. Takie rozumienie istoty polityki bezpieczeństwa morskiego determinować powinno także założenia polskich koncepcji zapewniania bezpieczeństwa oraz sposobu organizacji i funkcjonowania systemu bezpieczeństwa morskiego.
\end{abstract}

Słowa kluczowe. Bałtyk, bezpieczeństwo państwa, bezpieczeństwo społeczno-gospodarcze, polityka morska

Region zlewiska Morza Bałtyckiego, określanego niekiedy jako Europa Bałtycka, traktowany jest jako obszar stabilności politycznej. Zapewniać ją mają zarówno powiązania społeczno-kulturowe i gospodarcze państw regionu, jak i zbudowane na przestrzeni lat 90 . XX wieku wojskowe i polityczne środki budowy zaufania ${ }^{1}$. Przyjęte zasady kooperacji oraz rozwiązywania problemów regionalnych w praktyce niwelują możliwość zaistnienia poważnego kryzysu politycznego zmierzającego do wzajemnego użycia siły przez państwa regionu². Stabilizacja ta jest jednak ograniczona uwarunkowaniami gospodarczymi, wynikającymi ze strategii morskich państw regionu i mocarstw morskich, zainteresowanych uczestnictwem w prowadzeniu na tym akwenie nieskrępowanej żeglugi. Bałtyk stał się od pierwszej dekady XXI wieku nie tyle regionalnym akwenem morskim i szlakiem transportowym, co ważnym

1 Zestawienie najważniejszych dokumentów i prezentację ich zapisów zob. D. Rossa-Kilian, Region Morza Bałtyckiego obszarem rozwoju i współpracy. W świetle dokumentów, Toruń 2006.

2 Zob. m.in. K. Rokociński, Zagrożenia asymetryczne w regionie Morza Bałtyckiego, Warszawa 2006, P. Mickiewicz, Uwarunkowania polityczne, gospodarcze i obronne strategii bezpieczeństwa morskiego Rzeczypospolitej Polskiej, [w:] Strategia bezpieczeństwa narodowego Polski, red. J. Gryz, Warszawa 2013, s. 375-399. 
elementem globalnego systemu transportowego ${ }^{3}$. Rocznie przez akwen bałtycki przewozi się około $7 \%$ ogółu światowego wolumenu towarów, co przy jego wielkości powoduje duże zagęszczenie ładunku. Jest ono o prawie 500\% większe niż średnia światowa ${ }^{4}$. Zjawisko to prowadzi do indywidualizacji (niekiedy wręcz stosowania polistrategii) narodowych polityk państw regionu. W wymiarze polityczno-militarnym za potencjalnie konfliktogenne uznać należy - obecnie niekreujące istotnego zagrożenia, ale nierozwiązane - problemy graniczne. Są to przede wszystkim polsko-duńska strefa sporna wokół wyspy Bornholm i polsko-niemiecki problem kotwicowiska i toru podejściowego do Świnoujścia ${ }^{5}$, specyficzne ograniczenia zasady wolności żeglugi w Cieśninie Pilawskiej ${ }^{6}$ oraz problemy z uznawalnością kształtu granic morskich pomiędzy republikami bałtyckimi i Federacją Rosyjską.

Zaprezentowane uwarunkowania polityczne powodują, że przy niewielkiej skali zagrożenia wystąpienia napięcia politycznego, zmierzającego do użycia siły militarnej, uwzględnić należy możliwość wystąpienia kryzysu politycznego i pojawienia się zagrożeń bezpieczeństwa o charakterze politycznym. Ewentualny kryzys może wynikać przede wszystkim $\mathrm{z}$ form realizacji narodowych strategii $\mathrm{w}$ odniesieniu do regionu oraz związanej z nimi koncepcjami prowadzenia morskiej działalności wojskowej. Dlatego też ważne jest określenie możliwych obszarów konfliktogennych w oparciu o gospodarczo-polityczne koncepcje aktywności bałtyckiej państw regionu oraz założenia strategii bezpieczeństwa narodowego w odniesieniu do tego akwenu.

3 Szczegółowo proces ten można ocenić, analizując dane o skali i charakterze przewozów publikowane między innymi w corocznych „Rocznikach Strategicznych Gospodarki Morskiej”, wydawanych przez Urząd Statystyczny. Analizę za lata 2010-2012 przedstawiam w: P. Mickiewicz, Morze Bałtyckie w polskiej strategii bezpieczeństwa morskiego, Wrocław 2012, s. 116-142.

4 Średnia roczna częstość ładunku na Bałtyku wynosi 800 ton na km², zaś średnia światowa to 15 ton na $\mathrm{km}^{2}$.

5 Stronami sporu są Polska i NRD, a po zjednoczeniu Republika Federalna Niemiec. Już po wstąpieniu Polski do Unii Europejskiej miały miejsce trzy sytuacje sporne. 1 grudnia 2004 r. doszło do zatrzymania, pracującej na zlecenie Urzędu Morskiego w Szczecinie, holenderskiej pogłębiarki Cornelia. Zdaniem władz niemieckich prowadziła ona prace na obszarze wyłącznej strefy ekonomicznej Republiki Federalnej Niemiec. Kolejny incydent wystąpił 16 sierpnia 2006 r. Na akwenie tym odbyły się ćwiczenia niemieckiej marynarki wojennej RFN, o których nie poinformowano strony polskiej. Kolejny incydent nastąpił 17 października 2006 roku, a stroną był duński armator oraz polskie i niemieckie służby graniczne i celne. Duński statek „Adler Dania”, prowadząc sprzedaż pasażerom alkoholu i papierosów bez polskich znaków akcyzy, wpłynął na polskie wody terytorialne. Znajdujący się na pokładzie nieumundurowani celnicy przystąpili do kontroli, a kapitan zdecydował się na zmianę kursu i wejście na niemieckie wody terytorialne. Uniemożliwił w ten sposób kontrolę, a po wejściu na wody niemieckie organy celne RFN uznały, że nie złamano prawa.

6 Wśród potencjalnych zagrożeń bezpieczeństwa regionalnego o charakterze politycznym wskazać należy także konsekwencje zaangażowania się państw bałtyckich w pozaregionalne procesy stabilizacji politycznej oraz zwalczanie zagrożenia terrorystycznego. Uznający się za ofiary tego zaangażowania bojownicy mogą podjąć próbę przeprowadzenia zwłaszcza aktów terroru, skierowaną wobec społeczeństw i samych państw bałtyckich. 


\section{Gospodarcze koncepcje wykorzystania Morza Bałtyckiego w polityce regionalnych mocarstw morskich}

Zgodnie z definicjami teoretyków strategii morskiej w zlewisku Morza Bałtyckiego funkcjonują dwa państwa o potencjale pozwalającym nadać im status regionalnego mocarstwa morskiego (mocarstwa morskiego II kategorii) ${ }^{7}$. Są to Republika Federalna Niemiec i Federacja Rosyjska. Niemcy formalnie w regionie bałtyckim prowadzą politykę samoograniczenia swej pozycji jako mocarstwa morskiego. Większość swojej aktywności politycznej koncentrują na działaniach sprowadzanych do wdrażania regionalnych strategii i polityk Unii Europejskiej oraz przedsięwzięciach regionalnych organizacji międzynarodowych. Jednak w istocie polityka ta sprowadza się do kreowania pożądanych przez państwo niemieckie procesów gospodarczych poprzez realizację poszczególnych polityk UE oraz przez bilateralną kooperację o charakterze gospodarczym z Federacją Rosyjską. Jej skala i konsekwencje dla państw regionu nadają jej jednak charakter polityczny i jako taki oddziałujący na regionalny poziom bezpieczeństwa. Jednak należy podkreślić, że niemiecka aktywność ma charakter wtórny wobec rosyjskiej strategii bałtyckiej i sprowadza się do realizacji własnych przedsięwzięć, prowadzonych w dodatku na własnym terytorium. Ale skala powiązań gospodarczych powoduje, że regionalna pozycja Rosji jako mocarstwa morskiego jest skutecznie ograniczana przez RFN, gdyż to niemieckie porty są zasadniczym elementem rosyjskiego systemu transportowego w odniesieniu do północnej części Europy i kontynentów amerykańskich ${ }^{8}$.

Rosyjska polityka bałtycka jest klasyczną polityką prowadzoną przez mocarstwo morskie na akwenie ważnym, ale nie najistotniejszym dla całokształtu jego polityki. Wynika ona $\mathrm{z}$ celów strategicznych określonych w narodowej polityce morskiej, będącej także jednym z elementów pakietu przedsięwzięć zakładających odbudowę mocarstwowej pozycji Rosji ${ }^{9}$. W tej strategii polityka bałtycka stanowi element regionalnej polityki morskiej Rosji na tak zwanym kierunku atlantyckim ${ }^{10}$. Wśród

7 Mocarstwa morskie I oraz II kategorii to państwa posiadające potencjał pozwalający na decydowanie o kształcie stosunków politycznych, ekonomicznych i militarnych w przynajmniej jednym regionie. Zasadniczym wyróżnikiem jest fakt posiadania floty ekspedycyjnej oraz uzbrojenia pozwalającego na oddziaływanie globalne lub regionalne. Natomiast tzw. państwa nadbrzeżne nie dysponują takim potencjałem, ale posiadają zdefiniowane interesy na akwenach morskich oraz aspiracje ich realizacji. Są ulokowane na akwenach podległych ich jurysdykcji prawnej (tzw. małe państwa nadbrzeżne) lub obejmują także akweny morza otwartego (średnie państwa nadbrzeżne).

8 Szerzej: P. Mickiewicz, Morze Bałtyckie w rosyjskiej polityce zagranicznej i strategii morskiej, „Rocznik Integracji Europejskiej”, 2013, 7, s. 147-161.

9 Zob. Морская доктрина Российской Федерации на период до 2020 года УТВЕРЖДАЮ Президент Российской Федерации В.Путин 27 июля 2001 г. Пр-1387, p. 3-10,http://www.scrf. gov.ru/documents/34.html.

10 Poza Bałtykiem „kierunek” ten obejmuje akweny Morza Śródziemnego, Czarnego, Azowskiego oraz północną część Atlantyku. Polityka ta jest też korelowana z działaniami na „kierunku” arktycznym. 
szczegółowych długookresowych celów narodowej polityki morskiej w odniesieniu do Morza Bałtyckiego i kreujących poziom stabilizacji polityczno-gospodarczej regionu wskazać należy kwestie:

- prób zdominowania przez rosyjskie porty i przewoźników równoleżnikowych tras żeglugowych na Bałtyku;

- zapewnienia bezpieczeństwa ekonomicznego i militarnego obwodu kaliningradzkiego i budowy morskiego systemu komunikacyjnego obwód kaliningradzki - Federacja Rosyjska;

- rozwiązania problemów rozgraniczenia obszarów morskich i szelfu kontynentalnego z sąsiadami (Estonia, Łotwa, Łotwa);

- zapewnienia odpowiednich warunków bazowania wszystkim elementom składowym potencjału morskiego służącym obronie suwerenności, integralności terytorialnej i praw Federacji Rosyjskiej na akwenie bałtyckim;

- podjęcia stabilnej współpracy gospodarczej z państwami regionu ze szczególnym uwzględnieniem wspólnej eksploatacji zasobów naturalnych ${ }^{11}$.

Prowadzona w oparciu o powyższe założenia polityka bałtycka charakteryzuje się jeszcze jedną cechą. Jest nią dążenie do przeniesienia poziomu kontaktów bilateralnych na graczy globalnych oraz prowadzenia polityki w odniesieniu do pozostałych państw przy uwzględnieniu ich pozycji regionalnej i globalnej, a nie w kontekście położenia geograficznego względem Rosji. W tej koncepcji rolę europejskich partnerów, w tym także w wymiarze regionalnym, odgrywa sama Unia Europejska oraz mocarstwa regionalne - RFN, Francja i Wielka Brytania. Dotyczy to także regionu bałtyckiego, w którym dla Rosjan główną rolę odgrywają Niemcy, a istotne znaczenie mają najważniejsi europejscy partnerzy handlowi (Francja, Holandia, Wielka Brytania), państwa mogące oddziaływać na poziom rosyjskiego eksportu surowców energetycznych (Norwegia) oraz kraje tranzytu rosyjskiej wymiany handlowej z Europą. Rosyjska wymiana handlowa z Niemcami, Holandią, Francją i Wielką Brytanią oraz Włochami to równowartość 30\% całości obrotów wynoszących 71129 mld dol. ${ }^{12}$ Podstawą eksportu są nośniki energii, a rosyjskie przedsiębiorstwa importują głównie maszyny i urządzenia techniczne, wyroby chemiczne i metalurgiczne, tekstylia oraz drewno. Większość towarów przewożona jest transportem kolejowym, rzadziej wykorzystywany jest transport kołowy, a żegluga w tym rodzaju towarów

Ibidem, s. 15-18.

11 Ibidem, s. 16-17.

12 Federalny Urząd Statystyczny podaje jedynie, że eksport do Holandii wyniósł 13,6\% całości rosyjskiego eksportu, do Włoch 6,9\%, Polski - 3,8\%, Francji i Finlandii po 3,1\%, a do Wielkiej Brytanii - 2,9\%. Distribution of export and import of the Russian Federation by some foreign countries. Zob. Federal State Statistic Service, Russian Federation, www. http://www.gks.ru/bgd/regl/b10_12/ isswww.exe/stg/d02/26-07.htm 
ma charakter marginalny. Drogą morską przewożone są głównie ropa naftowa i jej przetwory oraz sprowadzane do Rosji maszyny o dużych gabarytach.

W tym miejscu podkreślić należy rolę nowego - występującego od 2010 roku - zjawiska, jakim jest zastępowanie przez chińskich eksporterów morskiego szlaku dostaw towarów do Europy Północnej trasami kolejowymi. Udostępnienie pozarosyjskim, zwłaszcza chińskim, eksporterom trasy Kolei Transsyberyjskiej pozwoliło na skrócenie czasu dostaw towarów o 1/3, co stanowi istotny powód do ograniczenia dostaw kontenerowych drogą morską wokół wybrzeży Azji i Europy ${ }^{13}$. Ponadto rozwiązanie to pozwala Rosji na uzyskanie kolejnego środka nacisku na państwa regionu. Odnosi się to zwłaszcza do krajów nordyckich, dla których wymiana handlowa z państwami Dalekiego Wschodu stanowi prawie 50\% ogółu przewozów kontenerowych ${ }^{14}$.

Tak skonstruowana polityka wskazuje jednoznacznie na prymat czynnika ekonomicznego i zmianę podejścia do kwestii bezpieczeństwa. Traktowany niekiedy wręcz w kategoriach ideologicznych stosunek Rosji do obecności Paktu Północnoatlantyckiego $\mathrm{w}$ regionie bałtyckim zaczyna odgrywać marginalną rolę. Celem polityki bezpieczeństwa staje się zapewnienie bezpieczeństwa wymiany handlowej, zwłaszcza nośników energii, oraz usankcjonowanie pozycji głównego dostawcy tych nośników do państw europejskich. Przedstawione cele polityki zagranicznej powodują, że państwa bałtyckie nie są traktowane jako kraje ważne dla Federacji Rosyjskiej, ale taką rolę odgrywa sam region. Zdefiniowana w Doktrynie morskiej Federacji Rosyjskiej do 2020 roku rola Bałtyku i regionu sprowadza się do uznania tego akwenu za najważniejszy strumień transportowy, pozwalający także na uzyskanie środków niezbędnych do usankcjonowania mocarstwowej pozycji państwa ${ }^{15}$. Z tego powodu celem rosyjskiej polityki bałtyckiej jest rozwój stabilnej współpracy gospodarczej z państwami regionu Morza Bałtyckiego i budowa zintegrowanego bałtyckiego systemu transportowego ${ }^{16}$.

Dominujący w rosyjskiej polityce bałtyckiej cel, jakim jest zdominowanie przewozów bałtyckich w układzie wschód-zachód, określa nie tylko rolę portów w Ust-Łudze ${ }^{17}$, Baltijsku oraz Sankt Petersburgu, ale przede wszystkim charakter bilateralnych stosunków z drugim mocarstwem regionalnym, czyli RFN. Priorytetowym

${ }^{13}$ Czas transportu kontenerów z Chin do Europy drogą lądową wynosi około 14 dni, zaś przy wykorzystaniu żeglugi dalekomorskiej wzrasta do miesiąca.

14 Wymiana krajów Dalekiego Wschodu ze Szwecją to 49\% ogółu jej obrotów kontenerowych, dla Finlandii $46 \%$, a w przypadku Norwegii poziom ten to równe $50 \%$.

15 Морская доктрина Российской Федерации на период до 2020 года, op. cit., s. 10.

16 Zob. Russian Federation. Transport Strategy until 2020. Reviewed by the meeting of the State Council of the Russian Federation on October 29, 2003, s. 22 i 29. http://lnweb90.worldbank.org/ eca/Transport.nsf/ECADocByUnid/C1267366F7DDF5FB85256EAE004AD3DC?Opendocument.

17 Ust'-Ługa jest portem położonym $110 \mathrm{~km}$ na zachód od St. Petersburga. 
celem tej współpracy jest utworzenie Zintegrowanego Bałtyckiego Systemu Transportowego o przepustowości $160 \mathrm{mln}$ ton rocznie ${ }^{18}$. Połączy on nie tylko wymienione porty rosyjskie z niemieckimi Sassnitz-Mukran i Rostok) ${ }^{19}$, lecz także zapewni stałe połączenie z najważniejszymi niemieckimi hubami przeładunkowymi, czyli portami w Bremie i Hamburgu. Rozwiązanie to umożliwi prowadzenie bezpośredniej wymiany handlowej drogą morską z głównymi rosyjskimi partnerami handlowymi, czyli Brazylią, Kanadą, Holandią, Włochami, Francją i Wielką Brytanią.

Znaczenie bałtyckiego strumienia transportowego w rosyjskiej polityce dodatkowo podnosi kolejny cel strategiczny, jakim jest dążenie do utrzymania statusu głównego europejskiego dostawcy surowców energetycznych ${ }^{20}$. Największym ograniczeniem dla rosyjskiego eksportu surowców do Europy są problemy tranzytowe oraz konieczność stałego związania się z odbiorcami w wyniku prowadzenia dostaw rurociągami. Dlatego też przyjęte w strategii energetycznejej rozwiązanie zakłada zwiększenie dostaw poprzez zbiornikowce, co znacząco zwiększa możliwości uzyskania nowych rynków zbytu. W koncepcji tej centralne miejsce zajmuje akwen Morza Bałtyckiego, gdyż rosyjska strategia energetyczna priorytetowe znaczenie nadała eksportowi za pośrednictwem Bałtyckiego Systemu Rurociągowego (BTS 2) oraz gazociągu Nord Stream 22 .

Zaprezentowane plany niemiecko-rosyjskiej kooperacji gospodarczej określają zarówno regionalny układ sił, jak i kreują określone zjawiska ekonomiczno-polityczne. Przede wszystkim prowadzona przez Rosjan i Niemców polityka ograniczy znaczenie dotychczasowych centrów eksportowych, zwłaszcza posiadającego połączenia $\mathrm{z}$ rosyjskim systemem transportu gdańskiego Naftoportu (będącego jednym z elementów systemu przesyłu Przyjaźń), jak i niebędących w tym systemie:

18 Oznacza to radykalny spadek przeładunków w portach pozostałych państw regionu. Dla ukazania skali tego spadku wystarczy wskazać, że porty Finlandii w pierwszej dekadzie XXI wieku obsługiwały około $6 \mathrm{mln}$ ton towarów kierowanych do i z Rosji, a porty Litwy, Łotwy i Estonii obsługiwały w sumie $47 \mathrm{mln}$ ton rocznie.

${ }^{19}$ Linie te obsługują promy towarowe, kolejowe i kolejowo-samochodowe, które mogą przewozić wagony o rosyjskim rozstawie kół.

${ }^{20}$ Rosja w 2010 r. stała się samodzielnym liderem w wydobyciu ropy naftowej. Wynosi ono $495 \mathrm{mln}$ ton ropy, co w przeliczeniu daje wynik dziennego wydobycia na powyżej 10 baryłek. Tym samym Federacja Rosyjska stała się samodzielnym liderem i jedynym państwem na świecie, które jest zdolne do wydobycia tej ilości ropy.

21 Енергетиетическая стратегийа России на период до 2030 г..., www.energystrategy.ru

22 Pierwszoplanowe znaczenie mają, uzyskujący moc przeładunkową na poziomie $120 \mathrm{mln}$ ton, port Primorsk oraz Ust-Ługa (o mocy przeładunkowej $38 \mathrm{mln}$ ton rocznie). Ma to pozwolić na przeładunek około $160 \mathrm{mln}$ ton ropy, zakładając, że rosyjskie porty obsługiwać będą od 75 do $95 \%$ całości obrotów. Pozwoli to także na zmniejszenie uzależnienia od europejskich importerów, gdyż zmniejszy się poziom dostaw przez system ropociągów. Przejęcie roli głównego środka dystrybucji ropy przez terminale portowe i zbiornikowce stwarza możliwość swobodnego kreowania polityki eksportowej i jej wykorzystywania do realizacji celów politycznych Federacji. 
łotewskiego portu w Ventspils i Tallinie oraz litewskich portów Butinga i Kłajpeda 23 . Ponadto oddziaływać będzie na państwa nordyckie, zwłaszcza Finlandię i Szwecję, gdyż jej efektem będzie zdominowanie przez rosyjskich przewoźników (i porty) przewozów wokół Zatoki Fińskiej.

W kontekście stricte militarnym jako konsekwencję budowy rosyjsko-niemieckiego Zintegrowanego Systemu Transportowego przez Bałtyk wskazać należy przeobrażenia portów obwodu kaliningradzkiego (Bałtijsk ${ }^{24}$, Swietły, Kaliningrad25). Wdrożone do końca 2015 roku programy rozwojowe zapewnią transport ładunków wojskowych z pominięciem ich tranzytu przez państwa członkowskie $\mathrm{NATO}^{26}$. Natomiast w kontekście politycznym wdrażane przez Rosjan i Niemców rozwiązania gospodarcze pozwalają na uzyskanie skutecznego instrumentu oddziaływania na regionalne procesy polityczno-gospodarcze. Najważniejsze inwestycje w postaci gazociągu Nord Stream, rozbudowy portów bałtyckich oraz systemu ich bezpośrednich połączeń w praktyce prowadzą do stopniowej marginalizacji znaczenia dotychczasowych, leżących poza terytorium Federacji portów przeładunkowych rosyjskiej wymiany handlowej. Jednocześnie polityka wymuszonego pozostania tych portów w rosyjskim systemie połączeń ma na celu zarówno ograniczenie ich roli przeładunkowej, jak i pośrednie związanie gospodarcze byłych republik radzieckich z rosyjską polityką gospodarczą w odniesieniu do regionu bałtyckiego. Funkcjonujące już zespoły portów Kaliningrad - Kłajpeda oraz Windawa - Ryga - Tallin - Sankt Petersburg i Ust-Ługa stanowią istotny element systemów przeładunkowych i pośrednio zmuszają byłe republiki radzieckie do tonowania zdecydowanie antyrosyjskiej polityki.

${ }^{23}$ Inwestycje te pozwalają nie tylko na eksport surowca do państw Unii Europejskiej, ale mogą być wykorzystywane jako dodatkowa trasa eksportu do nowych rynków zbytu.

${ }^{24}$ Port w Bałtijsku i nowy obiekt portowy zlokalizowany na półwyspie Wostocznyj posiadać będzie zdolność do obsługi promów i jednostek o wyporności 40 tys. ton. Na jego obszarze, poza terminalami promowymi, zlokalizowane są terminale drobnicy, płynnych ładunków chemicznych i przetworów ropy naftowej. Roczna wielkość przeładunków wynosi $34 \mathrm{mln}$ ton, w tym udział przetworów ropy naftowej to $20 \mathrm{mln}$ ton.

25 Port w Kaliningradzie, będący jedynym dużym i niezamarzającym portem rosyjskim na Bałtyku wykorzystywany jest do przeładunku produktów naftowych na poziomie 1540 tys. ton rocznie. Posiada także nabrzeże rzeczne, co pozwala na transport towarów nie tylko szlakami szynowymi, lecz także żeglugą śródlądową. Posiadający 22 stanowiska cumownicze port ma również dwa systemy przeładunkowe dla jednostek ro-ro i trzy do rozładunku zboża wraz z elewatorami. Jego moce przeładunkowe zwiększa także możliwość wykorzystania nabrzeży rybackich, które są przystosowane do obsługi innych ładunków, w tym kontenerowych, drobnicowych, płynnych i sypkich. W porcie rybackim możliwa jest obsługa około 650 jednostek i 25 tysięcy wagonów kolejowych rocznie.

26 Natomiast w wymiarze regionalnym zapewniają obsługę linii bałtyckich, zwłaszcza Arhus - Kilona - Kaliningrad - Tallin, Sankt Petersburg - Kaliningrad - Kilonia, Ust-Ługa - Bałtijsk - Mukran oraz Bałtijsk - Karlshamn - Ronneby - Karlskrona. 


\section{Prowadzenie morskiej działalności wojskowej w założeniach doktryn morskiej i bezpieczeństwa regionalnych mocarstw morskich}

Zaprezentowane powyżej koncepcje polityki bałtyckiej regionalnych mocarstw morskich określają także zakres narodowych planów wykorzystania posiadanego potencjału morskiego. Wynikające $\mathrm{z}$ tych koncepcji cele strategiczne na akwenie bałtyckim sprowadzić można do:

1) zapewnienia na tym akwenie powszechnego stosowania zasady wolności morza otwartego na każdym akwenie posiadającym ten status, $\mathrm{w}$ tym prawa do swobodnego układania systemów przesyłowych (rurociągi i połączenia kablowe) i budowy sztucznych wysp;

2) zagwarantowania warunków zezwalających na wykorzystanie walorów morza w polityce gospodarczej państwa i poszczególnych jego regionów.

W tym kontekście priorytetową formę oddziaływania regionalnego obydwu mocarstw stanowią instrumenty polityczno-dyplomatyczne i ekonomiczne. Natomiast morska działalność wojskowa sprowadzona została do działań mających na celu niwelowanie zagrożeń bezpieczeństwa, postrzeganych jako międzypaństwowe sprzeczności co do istoty wykorzystania akwenów morskich. Za najistotniejsze z tych sprzeczności uznano różniące się koncepcje państw w kwestii wykorzystywania obszarów o szczególnym statusie i strategicznym znaczeniu. W rosyjskiej polityce morskiej i działalności wojskowej na morzu szczególne znaczenie nadano kwestii zagwarantowania gospodarczych i politycznych interesów Federacji Rosyjskiej27. W kontekście bałtyckim cel ten sprowadza się do utrzymania ciągłości bałtyckiego systemu transportowego, zwłaszcza systemu transportu towarów i przesyłu nośników energii, przed działaniami państwowych i pozapaństwowych uczestników stosunków międzynarodowych. W drugiej kolejności siły morskie mają realizować zadania zapewniające podtrzymanie stabilności polityczno-gospodarczej na akwenach bałtyckich, obronę morskich granic Federacji oraz ochronę praw w poszczególnych obszarach morskich ${ }^{28}$. Przyjęte założenie powoduje, że rosyjska marynarka wojenna będzie utrzymywać stałą obecność na bałtyckich akwenach morskich oraz prowadzić działania rozpoznawcze w celu zapewnienia bezpieczeństwa ekonomicznego państwa, a także współuczestniczyć w systemie obrony granic i obszarów morskich Federacji. Jej potencjał ma też umożliwić pełne zabezpieczenie transportu specjalnego, przeprowadzenie ewentualnej blokady ekonomicznej (morskiej) oraz

\footnotetext{
27 Strategia Bezpieczeństwa Federacji Rosyjskiej, Doktryna Wojenna Rosji. Zob. Cmpamezuя национальной безопасности Российской Федерации до 2020 года, УТВЕРЖДЕНА Указом Президента Российской Федерации от 12 мая 2009 г. № 537. Указ Президента Российской Федерации „О Военной доктрине Российской Федерации” от 5 февраля 2010 г. N 146.

28 Zadania te obejmują także przedsięwzięcia związane ze zwalczaniem zagrożeń pozamilitarnych.
} 
podjęcie działań zmierzających do wymuszenia przestrzegania przez państwa trzecie uzgodnień międzynarodowych ${ }^{29}$.

Innymi czynnikami determinowana jest polityka bałtycka i strategia bezpieczeństwa morskiego Republiki Federalnej Niemiec. Państwo niemieckie ze względów polityczno-historycznych nie posiada oficjalnej strategii bezpieczeństwa. Rolę takiego dokumentu odgrywa Biała księga. Bezpieczeństwo Niemiec i przyszłości Bundeswehry ${ }^{30}$. Jej głównym przesłaniem jest obowiązek zapewnienia obywatelom Niemiec bezpieczeństwa i ochrony i tym samym oparta na tym dokumencie niemiecka polityka bezpieczeństwa nie odnosi się w sposób szczegółowy do kwestii morskich. Rolę akwenu bałtyckiego oraz ocenę zagrożeń można jednak odnaleźć w jej zapisach, gdyż wśród wymienionych zagrożeń bezpieczeństwa w kontekście subregionu bałtyckiego dominują zagrożenia o charakterze ekonomicznym, zwłaszcza związane $\mathrm{z}$ bezpieczeństwem transportu i wymiany handlowej, dotyczące systemów transportu surowców oraz bezpieczeństwa energetycznego. Zaś jednym z wykazanych w Białej księdze strategicznych interesów RFN jest wspieranie handlu międzynarodowego i zapewnienie bezpieczeństwa globalnemu systemowi transportowemu ${ }^{31}$. Dlatego też szczególne miejsce w niemieckiej polityce morskiej, także w odniesieniu do Bałtyku, zajmują: kwestia bezpieczeństwa żeglugi, w tym systemu transportu nośników energetycznych, stworzenie europejskiej przestrzeni transportu morskiego oraz zwiększenie konkurencyjności portów. W kontekście bałtyckim ważnym zadaniem jest także zwiększenie niezawodności transportu morskiego, ograniczenie zagrożeń związanych z transportem ładunków niebezpiecznych oraz poprawa zdolności do reagowania $\mathrm{w}$ razie wypadków lub wycieków na morzu ${ }^{32}$. Tym samym zadaniem sił morskich, poza przygotowaniem do obrony przed ewentualną agresją ze strony morza, jest ochrona morskich szlaków komunikacyjnych oraz zapewnienie swobody

${ }^{29}$ Wyjątkiem od tej koncepcji wykorzystania bałtyckich sił morskich w rosyjskiej doktrynie wojennej jest koncepcja wykorzystania obwodu kaliningradzkiego. Jego położenie geopolityczne w przypadku zaistnienia konfliktu zbrojnego wymaga prowadzenia działań w ramach tak zwanej operacji połączonej, co determinuje kształt stacjonujących sił zbrojnych oraz sposób dowodzenia.

30 Obowiązujący dokument przyjęto 25 października 2006 roku. Zob. Weißbuch 2006 zur Sicherheitspolitik Deutschlands und zur Zukunft der Bundeswehr, Bundesministerium der Verteidigung, Berlin 2006, http://www.weissbuch.de..

${ }^{31}$ Jest to oczywisty cel strategiczny w sytuacji, gdy około $30 \%$ niemieckiej wymiany handlowej prowadzone jest drogą morską, przemysł stoczniowy zajmuje czwarte miejsce na świecie, a przetwórstwa ryb - w Unii Europejskiej, a sektor gospodarki morskiej zatrudnia 0,5\% ogółu zatrudnionych w gospodarce narodowej. Zob. dane zawarte w „Rocznik statystyczny gospodarki morskiej 2010..., op. cit., s. 352.

${ }^{32} \mathrm{Na}$ niemieckim wybrzeżu Morza Północnego najważniejszym zadaniem jest minimalizacja negatywnych skutków oddziaływania zjawiska abrazji. Na jej działania narażona jest $1 / 3$ długości niemieckiego pasa nadmorskiego. 
żeglugi na wodach otwartych i suwerenności na akwenach morskich znajdujących się pod jurysdykcją RFN ${ }^{33}$.

\section{Rola czynnika gospodarczego w polityce bałtyckich państw nadbrzeżnych}

Polityka bałtycka pozostałych państw subregionu musi w pierwszym rzędzie odnosić się do działań podejmowanych przez obydwa mocarstwa morskie. Oparta jest także na wspólnocie interesów i koncentruje się głównie na problematyce prowadzenia właściwej eksploracji i eksploatacji akwenu oraz wzajemnej wymiany handlowej. Podstawą są wymienione powyżej inicjatywy rozwojowe Unii Europejskiej w odniesieniu do regionu, uzupełniane poprzez rozwiązania podejmowane w ramach układów regionalnych. Narodowe polityki bałtyckie są natomiast prowadzone w oparciu o teoretyczne zasady funkcjonowania państwa nabrzeżnego. Jednak poziom uzależnienia gospodarek od poziomu i charakteru przewozów morskich oraz zagrożenia kreowane przez te przewozy powodują, że kwestia ta determinuje także kształt prowadzonej polityki bałtyckiej i polityki bezpieczeństwa narodowego. Dotyczy to zwłaszcza państw północnej części zlewiska (Szwecji, Finlandii, Norwegii, a także - w mniejszym stopniu - Danii) oraz Polski. Ich koncepcje rozwoju gospodarczego w istotnym stopniu uwzględniają prorozwojową rolę transportu morskiego - wymiany handlowej prowadzonej przy wykorzystaniu szlaków bałtyckich w oparciu o ich porty. W przypadku tych państw porty pełnią funkcję ogniwa łączącego nie tylko państwa, lecz także miasta i lokalne rynki, a także są naturalnym przedłużeniem lądowych korytarzy transportowych ${ }^{34}$. Obydwie cechy powodują, że celem politycznym bałtyckich państw nadbrzeżnych jest utrzymanie obecnej struktury przeładunku towarów. Dotyczy to zwłaszcza państw nordyckich, których udział w bałtyckim systemie przeładunkowym wynosi około $37 \%{ }^{35}$. Jednak w wyniku zaprezentowanych powyżej koncepcji kooperacji gospodarczej bałtyckich mocarstw morskich porty te są wypierane z rynku przeładunkowego, zwłaszcza w dominujących grupach towarów tranzytowych. Podobny problem dotyczy

\footnotetext{
${ }^{33}$ Siły morskie są wykorzystywane jako ważny instrument polityki RFN. Stanowią istotny kontyngent sił NATO i UE. Ze względu na poziom importu surowców energetycznych znaczna aktywność skoncentrowana jest na akwenie Morza Śródziemnego i północnego Atlantyku. Zadanie sił morskich w rejonach oddalonych to ochrona transportu osób i techniki wojskowej w rejonie kryzysów, ochrona i kontrola linii żeglugowych, realizacja przedsięwzięć w ramach sił sojuszniczych oraz zapobieganie nielegalnemu transportowi broni masowego rażenia. Zob. J. Mannhardt, Der Maritime Beitrag im Aufgabenspektrum der Bundeswehr. Konzeptionelle Vorstellungen, Fähigkeiten und Perspektiven, „Soldat und Technik”, 2004, nr 4, s. 47-48.

34 Szerzej, P. Mickiewicz, Morze Bałtyckie..., op. cit., s. 130-142.

35 Państwa nordyckie posiadają w sumie 220 portów, czyli 70\% wszystkich zlokalizowanych na Bałtyku miejsc przeładunku towarów, w tym 89 to porty szwedzkie, 81 duńskie, 49 znajduje się w Finlandii, a 200 funkcjonuje w Norwegii. Dla porównania Polska posiada 11 portów, a RFN 25.
} 
portów republik bałtyckich w odniesieniu do przewozu ropy naftowej i jej pochodnych. Rosyjskie plany eksportowe przewidują bowiem nie tylko wzrost wielkości eksportu, ale przede wszystkim jego prowadzenie przy wykorzystaniu własnych terminali paliwowych. Kosztem portów w Rydze, Tallinie (Muuga), Ventspils, Kłajpedzie i Butinge oraz - w mniejszym stopniu -w Gdańsku. Przeciwdziałanie tym procesom w formule innej niż antagonistyczna sprowadza się jedynie do wdrożenia obostrzeń dotyczących bezpieczeństwa żeglugi (stanu bezpieczeństwa jednostek wpływających na akwen) oraz utrzymania zasady, że podstawowym środkiem przewozu będą średnie jednostki handlowe (o wyporności ok. 150000 BRT). Negatywem tego rozwiązania jest ich duża liczba, którą należy szacować na 2000 jednostek prowadzących żeglugę bałtycką pływających dziennie ${ }^{36}$. To przenosi się wprost na poziom zagrożenia kolizjami, a tym samym lokalne wystąpienie skażenia wód. Bez względu na obszar skażenia w warunkach Morza Bałtyckiego przyjmuje ono praktycznie w każdym przypadku charakter miejscowej katastrofy ekologicznej37. Ogranicza to także zakres kontroli granicznej, co przekłada się wprost na skalę działań przestępczych, zwłaszcza przemytu towarów.

Osobnego potraktowania wymaga casus Polski jako bałtyckiego państwa nadbrzeżnego. Wynika to nie tyle z potencjału morskiego Rzeczpospolitej, który jest niski i nie odgrywa istotnej roli gospodarczej. Tak zwana gospodarka morska ${ }^{38}$ wytwarza zaledwie $0,9 \%$ całości przychodów państwa, a tworzy ją $0,3 \%$ polskich podmiotów gospodarczych, zatrudniających $0,6 \%$ ogółu pracowników najemnych ${ }^{39}$. Niewielki udział gospodarki morskiej w kreowaniu PKB nie ogranicza jednak polskich interesów na Bałtyku. Zostały one bowiem ulokowane w innych obszarach aktywności polityczno-gospodarczej. W sferze gospodarczej celem Polski jest przekierowanie części przewozów tranzytowych z Azji do Europy Północnej do polskich, zamiast rosyjskich portów, a także ich włączenie w system przewozów bałtyckich jako hub-portów dla dostaw towarów do państw regionu ${ }^{40}$. W tym kontekście równie istotnym celem strategicznym Rzeczpospolitej jest kwestia dywersyfikacji nośników i źródeł energii w postaci bezpieczeństwa dostaw gazu LNG do Terminala Gazowego

\footnotetext{
${ }^{36}$ Zob. BRISK - Sub-regional risk of spill of oil and hazardous substances in the Baltic Sea, http://www. brisk.helcom.fi.

37 P. Mickiewicz, Bezpieczeństwo energetyczne i ekologiczne Polski a rozbudowa bałtyckiego systemu transportu surowców energetycznych, [w:] „Rocznik Bezpieczeństwa Międzynarodowego” 2009/2010,Wrocław 2010, s. 55-72.

38 Gospodarka morska to „system działalności gospodarczej i jej skutków związany ze środowiskiem morza i jego zlewisk, polegający na produkcji i przetwórstwie, podziale oraz konsumpcji dóbr i usług oraz morskim planowaniu przestrzennym”. Zob. Polska Klasyfikacja Działalności (PKD 2007).

39 Zob. „Rocznik Statystyczny Gospodarki Morskiej 2012”, Główny Urząd Statystyczny i Urząd Statystyczny w Szczecinie, Szczecin 2011, s. 24-27.

40 Do roku 2010 rolę taką wypełniały porty Hamburg, Brema i Kopenhaga. Natomiast obecnie coraz większą popularnością wśród największych przewoźników (np. firmy Maersk) cieszy się Gdańsk. „Rocznik Statystyczny Gospodarki Morskiej 2011..., op. cit., s. 362-367.
} 
w Świnoujściu oraz funkcjonowania marinokultur wiatrowych na akwenach polskiego wybrzeża środkowego ${ }^{41}$. Należy także podkreślić rolę podmorskich złóż gazu łupkowego leżących w polskiej Strefie Wyłączności Ekonomicznej. Ich eksploatacja może stanowić jeden z głównych celów aktywności morskiej państwa, co rzutować będzie na zagrożenia bezpieczeństwa morskiego Rzeczpospolitej. Przekłada się to bezpośrednio na cele oddziaływania politycznego w regionie. Państwo polskie, ze względu na charakter interesów ekonomicznych, musi prowadzić politykę ograniczania regionalnej dominacji Rosji i RFN, zwłaszcza w sferze przewozów morskich. Zasadniczym środkiem oddziaływania jest kooperacja bałtycka prowadzona w ramach stosunków bilateralnych i układów regionalnych. Dzięki właściwemu skorelowaniu narodowych interesów z interesami państw nordyckich (ograniczenie tranzytu towarów poprzez rosyjskie porty i zwiększenie bezpieczeństwa żeglugi) oraz republik bałtyckich (ograniczenie przeładunku ropy i jej przetworów w rosyjskich portach kosztem innych terminali paliwowych) jest w stanie zarówno zapewnić ich właściwą ochronę, jak i budować pozycję ważnego gracza regionalnego.

\section{Prowadzenie morskiej działalności wojskowej w założeniach doktryn morskiej i bezpieczeństwa państw nordyckich i Bałtów}

Ze względu na usytuowanie regionalnych celów gospodarczych i politycznych kwestia bezpieczeństwa średnich i małych państw nadbrzeżnych w regionie bałtyckim ściśle wiąże się z poziomem bezpieczeństwa morskiego regionu. W przypadku państw nordyckich jest to konsekwencja udziału szeroko rozumianej gospodarki morskiej w narodowych systemach gospodarczych oraz - w mniejszym stopniu - obaw przed polityczno-militarnym zdominowaniem regionu przez Federację Rosyjską. Natomiast dla Bałtów czynnik zagrożenia rosyjskiego, zwłaszcza w konsekwencji problemów w stosunkach bilateralnych, stanowi główny wyznacznik narodowych polityk bezpieczeństwa. Uwarunkowania te, dysproporcja potencjałów oraz okoliczności historyczne powodują, że kraje te zdecydowały się na głęboką korelację własnych polityk morskich, regionalnych i narodowych strategii bezpieczeństwa. Kooperacja państw nordyckich przebiega $\mathrm{w}$ dwóch wzajemnie skorelowanych wymiarach, które

\footnotetext{
${ }^{41}$ Warunki meteorologiczne panujące na polskich akwenach morskich pozwalają na ich budowę wzdłuż całego wybrzeża, a sumaryczna wartość produkcji energii elektrycznej, wyliczona w oparciu o zapisy złożonych do połowy 2012 roku wniosków o udzielenie koncesji na ich budowę, wynosi $6 \mathrm{GW}$. W Krajowym planie działań w zakresie energii ze źródeł odnawialnych przewidziano, że docelowa moc produkcyjna ferm wiatrowych wyniesie 0,5 gigawatów. Tymczasem inwestorzy złożyli wnioski o budowę 6 marinokultur wiatrowych, a tylko koncern Polska Grupa Energetyczna oferuje budowę ferm o przewidywanej mocy 1000 megawatów do 2015 roku, a docelowo 2000 MW w 2020 roku. Zob. Krajowy plan działań w zakresie energii ze źródeł odnawialnych, Ministerstwo Gospodarki, Warszawa 2009 (wersja przekazana 9 grudnia 2009 do Komisji Europejskiej), s. 9 i 62 oraz Budujemy wartość i bezpieczna przyszłość. Strategia Grupy PGE na lata 2012-2035, luty 2012, s. 9.
} 
określa się jako wspólnota bezpieczeństwa nordyckiego i nordycka równowaga ${ }^{42}$. Obydwa zakładają podjęcie szerokiej i wielowątkowej współpracy prowadzonej na szczeblu społeczeństw, regionów oraz samych państw, a w konsekwencji stworzenie systemu kolektywnej obrony i budowy wzajemnie uzupełniającego się potencjału obronnego. W wymiarze regionalnym celem jest przeniesienie tej współpracy na pozostałe państwa bałtyckie, w tym Rosję, oraz prowadzenie polityki mającej na celu zachowanie równowagi strategicznej. Z kolei polityka bezpieczeństwa republik postradzieckich zakłada budowę regionalnego sojuszu politycznego, na który nakłada się w sposób naturalny fakt członkostwa państw bałtyckich w strukturach Paktu Północnoatlantyckiego. Pozwala to na osiągnięcie strategicznego celu, którym jest równoważenie mocarstwowej pozycji Federacji Rosyjskiej w wymiarze polityczno-militarnym oraz RFN w wymiarze gospodarczo-politycznym. Za dokument stanowiący podstawę kooperacji nordyckiej współpracy w dziedzinie bezpieczeństwa uznać należy Raport Torvena Stoltenberga ${ }^{43}$. W ogłoszonym 9 lutego 2009 r. dokumencie ${ }^{44}$ określono trzynaście obszarów współpracy w dziedzinie bezpieczeństwa, uwzględniającej między innymi nawiązanie współpracy przy sprawach dotyczących Arktyki (satelitarny monitoring i rozpoznanie), wspólne patrolowanie przestrzeni powietrznej nad Islandią, powołanie wspólnych sił stabilizacyjnych państw nordyckich oraz prowadzenie wspólnych działań ochronnych przed atakiem cyberterrorystycznym. Podstawą współpracy jest tzw. deklaracja solidarności ${ }^{45}$ przewidująca obowiązek udzielenia pomocy przez państwo-sygnatariusza w razie ataku na inne państwo będące stroną tego porozumienia. Natomiast projektem o charakterze militarnym, określającym zakres kooperacji państw nordyckich, jest zaaprobowany w 2007 r. plan Nordic Supportive Demence Structures (NORDSUP) ${ }^{46}$. Zakłada on

42 O. Osica, M.A. Cichocki, Konsolidacja czy dezintegracja? Bezpieczeństwo w subregionie Morza Bałtyckiego, „Nowa Europa”, numer specjalny 2009, s. 23-24 i 26-43.

${ }^{43}$ Osobnym, ale świadomie pominiętym przez autora obszarem nordyckiej aktywności w sferze bezpieczeństwa jest uczestnictwo w europejskich procesach stabilizacyjnych. Jedynie w okresie lat 90 . XX wieku obejmowały one region bałtycki, a datę końcową wyznacza przyjęcie do NATO Litwy, Łotwy i Estonii. Od 1997 r. działania prowadzone w ramach Nordic Initiative for Regional Defence Cooperation oraz Nordic Co-ordinated Arrangement for Military Peace Support koncentrują się na obszarze Bałkanów Zachodnich.

44 T. Stoltenberg, Nordic Cooperation on Foreign And Security Policy, Proposals presented to the extraordinary meeting of Nordic foreign ministers in Oslo on 9 February 2009.

45 Deklaracja podpisana została dopiero 5 kwietnia 2011 roku, gdyż Szwecja i Finlandia prezentowały stanowisko, że pozostaje ona w sprzeczności z prowadzoną przez nie polityką nieangażowania. Zapis ten po modyfikacjach przyjął następujące brzmienie: „gdyby któryś z nich [państw-sygnatariuszy, przyp. PM] został dotknięty klęską lub atakiem, pozostali sygnatariusze, po uprzednim wyrażeniu przez ten kraj takiego życzenia, pomogą mu w uporaniu się z sytuacją poprzez dostarczenie odpowiednich środków".

46 Jego inicjatorami byli szefowie sztabów generalnych Norwegii, Szwecji i Finlandii, a od listopada 2008 roku w określonych w nim działaniach uczestniczą oficjalnie także Dania i Islandia. 
budowę wspólnej strategii obrony terytorium państw uczestniczących w projekcie poprzez proces integracji wybranych rodzajów sił zbrojnych i pojedynczych jednostek wojskowych oraz wspólną koordynację programów rozwojowych dotyczących szeroko rozumianej sfery bezpieczeństwa.

Podkreślić jednak należy, że w duńskiej i norweskiej polityce bezpieczeństwa region bałtycki jest traktowany poprzez pryzmat jego regionalnej roli, ale także w kontekście rosyjskiej polityki atlantyckiej. Jak zaprezentowano powyżej, istotą tej polityki (kierunku atlantyckiego rosyjskiej polityki morskiej) jest uzyskanie możliwości eksploracji Arktyki i jej akwenów morskich. W istotny sposób determinuje to kształt narodowych polityk bezpieczeństwa obydwu państw nordyckich. Określa na nowo kształt sojuszy politycznych, co w przypadku Norwegii sprowadza się do wykorzystywania w polityce bałtyckiej pozycji i interesów Wielkiej Brytanii, a nade wszystko podtrzymywania amerykańskiej obecności na akwenach Europy Północnej, i powoduje wzrost norweskiej aktywności w regionie, traktowanej jako instrument zezwalający na stosowanie nacisku na Rosję i Danię w kwestii ewentualnych sporów o eksploatację złóż arktycznych. Natomiast w polityce Królestwa Danii w odniesieniu do Morza Bałtyckiego wyróżnić można dwa obszary aktywności. Konieczność kontroli akwenów morskich i morskiego ruchu towarowego z Atlantyku i Morza Północnego na Bałtyk powoduje, że Dania podjęła współpracę w sferze bezpieczeństwa morskiego z europejskimi państwami nadmorskimi, a zwłaszcza z Wielką Brytanią i Holandią. Drugim obszarem aktywności, lecz o mniejszym znaczeniu, jest kształtowanie sytuacji polityczno-gospodarczej w regionie bałtyckim. Postrzegana jest ona coraz bardziej w kontekście kooperacji nordyckiej oraz możliwości zaistnienia zagrożeń pozamilitarnych, $\mathrm{w}$ tym zorganizowanej przestępczości i terroryzmu ponowoczesnego, traktowanego jako środek oddziaływania na państwo demokratyczne. Ocena skali tego zagrożenia spowodowała istotną zmianę duńskiej aktywności w ramach NATO oraz znaczne reformy sił zbrojnych ${ }^{47}$. Uznanie, że oprócz aktu terroru skierowanego na społeczeństwo celem takiego ataku może być szeroko rozumiana gospodarka morska, spowodowało także podjęcie całego spectrum przedsięwzięć ukierunkowanych na zapewnienie bezpieczeństwa żeglugi. Przyczyniło się to do dosyć ścisłego powiązania polityki bezpieczeństwa z polityką morską, której celem pozostaje zwiększanie konkurencyjności gospodarki morskiej, zwłaszcza związanej z rybołówstwem, turystyką oraz wymianą handlową. Z tego względu koncentruje się ona na problematyce tworzenia wielosektorowych klastrów morskich i tworzeniu kompleksowych systemów zarządzania gospodarczego regionami nadbrzeżnymi, rozwoju małych portów i turystyki morskiej oraz nadmorskiej, na zapewnieniu bezpieczeństwa żeglugi, prowadzeniu zrównoważonej eksploatacji zasobów Morza

\footnotetext{
47 Podkreślić jednak należy, że wzrost duńskiej aktywności w NATO oraz działania stabilizacyjne w wymiarze globalnym nie są powodowane próbą budowy pozycji politycznej państwa, ale wynikają właśnie z oceny skali zagrożenia terrorystycznego.
} 
Bałtyckiego, a także zagwarantowaniu bezpieczeństwa ekologicznego wybrzeża oraz akwenów morskich.

Odmiennie rolę regionu bałtyckiego postrzegają natomiast Szwecja i Finlandia. Polityka bałtycka zajmuje centralne miejsce w całokształcie szwedzkiej polityki, a dodatkowo jej znaczenie wzmacnia pełna akceptacja państw nordyckich co do jej głównej roli jako kreatora wspólnych działań w odniesieniu do regionu. Prowadzona przez Szwecję polityka bałtycka, podkreślając status państwa neutralnego, w sferze bezpieczeństwa zakłada aktywny udział zarówno w kreowaniu stosunków polityczno-gospodarczych $\mathrm{w}$ regionie, jak i budowie potencjału pozwalającego na zagwarantowanie odpowiedniego poziomu bezpieczeństwa. Podstawową formą oddziaływania w sferze bezpieczeństwa regionalnego jest kreowanie różnych form współpracy, a jej miejscem są układy regionalne oraz Unia Europejska ${ }^{48}$ i Sojusz Północnoatlantycki. Szczególne miejsce w szwedzkiej polityce, a zwłaszcza polityce bezpieczeństwa, zajmuje Rosja. Stosunki bilateralne oraz rosyjska polityka w regionie bałtyckim są postrzegane jako miernik poziomu bezpieczeństwa narodowego. $\mathrm{Za}$ jego zagrożenie uważa się rozbudowę wpływów politycznych oraz gospodarczych Federacji w regionie. Szwecja niezmiennie od lat 90 . XX wieku uznaje, że działania te w sposób pośredni zwiększają rosyjskie możliwości militarne i prawdopodobieństwo ewentualnego ataku na swoje terytorium. Ocena tego zagrożenia powoduje, że polityka bezpieczeństwa Królestwa Szwecji koncentruje się na trzech zadaniach, tj.: obronie terytorium przed atakiem z użyciem sił zbrojnych, współkreowaniu - poprzez aktywność dyplomatyczną oraz kooperację gospodarczo-polityczną - procesów stabilizacji polityczno-militarnej i tworzeniu ponadnarodowego bezpieczeństwa wspólnego w postaci określonych obszarów kooperacji skorelowanych z narodowymi i nieantagonistycznymi celami bezpieczeństwa. Takie podejście do problematyki bezpieczeństwa pozwala na zachowanie neutralności politycznej przy aktywnym udziale $\mathrm{w}$ procesach kreowania ładu międzynarodowego w wymiarze globalnym i regionalnym. Regionalna (bałtycka) aktywność Szwecji uwzględnia w zasadniczym stopniu interes narodowy, ściśle związany z gospodarką morską, która kreuje znaczną część dochodu narodowego, w sektorze tym pracuje 2,3\% czynnej zawodowo ludności. Morze Bałtyckie stanowi główny szlak wymiany towarowej, przez który transportowane jest aż $80 \%$ eksportu i importu. Akwen ten wykorzystywany jest także jako zasadnicza droga wewnętrznego transportu towarowego. W dodatku uwarunkowania geograficzno-klimatyczne powodują, że aż $40 \%$ populacji zamieszkuje obszar oddalony zaledwie $5 \mathrm{~km}$ od linii brzegowej, co zwiększa znaczenie eksploatacji bałtyckich zasobów ożywionych w szwedzkiej polityce morskiej. Sposób wykorzystania akwenu

$48 \mathrm{~W}$ wymiarze kontynentalnym szwedzka aktywność polityczna koncentruje się na budowaniu pozycji państw nordyckich w UE, aktywnym udziale w kształtowaniu Europejskiej Polityki Sąsiedztwa i działaniach poszerzających tę ideę, jak na przykład współkreowanie wraz z Polską polityki wschodniej UE. 
powoduje, że priorytetem strategii bezpieczeństwa morskiego jest zrównoważona eksploracja i eksploatacja zasobów ożywionych i nieożywionych oraz zapewnienie wysokiego poziomu bezpieczeństwa żeglugi.

Centralne miejsce w szwedzkiej polityce bezpieczeństwa zajmuje, niejako tradycyjnie, kwestia miejsca Królestwa Szwecji w rosyjskiej strategii. Doświadczenia okresu zimnej wojny oraz obawa przed siłowym rozwiązaniem rosyjskich roszczeń terytorialno-ekonomicznych w Arktyce nadal nadają temu problemowi rangę zasadniczego zagrożenia o charakterze politycznym. Z tego względu każdorazowa militarna aktywność Rosji postrzegana jest jako osłabienie poziomu bezpieczeństwa państwa. Konsekwencją takiego postrzegania polityki rosyjskiej jest bliska współpraca z Sojuszem Północnoatlantyckim i pojawiające się raz po raz dyskusje o zarzuceniu polityki neutralności, przystąpieniu do NATO lub utworzeniu nowego sojuszu politycznego, pozwalającego na minimalizowanie rosyjskiego zagrożenia przy zachowaniu statusu państwa neutralnego. Ten kierunek ewolucji polityki bezpieczeństwa powoduje, że w szwedzkim dyskursie politycznym stale obecna jest kwestia ścisłej kooperacji wojskowej państw nordyckich, w wariancie przedstawionym przez Thorvalda Stoltenberga, a także inne inicjatywy, w tym także koncepcje dotyczące podjęcia ścisłej współpracy wojskowej z RFN ${ }^{49}$, Polską oraz republikami bałtyckimi.

Przedstawione powyżej uwarunkowania polityczne sprawiają, że szwedzkie siły zbrojne zostały stworzone w celu zapewnienia bezpieczeństwa państwa. Jednak wszystkie dotychczasowe plany ich rozwoju uwzględniają także potencjał militarny państw nordyckich. Posiadają one zdolność do prowadzenia nawodnego i podwodnego monitorowania akwenów, prowadzonej na akwenach bałtyckich żeglugi oraz eksploatacji zasobów ożywionych i nieożywionych. Ze względu na dominującą zasadę solidaryzmu nordyckiego $\mathrm{w}$ ich strukturze znajdują się także okręty podwodne, których nie posiadają Dania i Finlandia, oraz znaczna liczba samolotów bojowych.

Dla Finlandii zasadniczą determinantą kształtu polityki bezpieczeństwa w odniesieniu do regionu bałtyckiego są doświadczenia historyczne. Powodują one, że kwestia bałtycka postrzegana jest przez aktywność trzech aktorów sceny międzynarodowej. Są nimi Federacja Rosyjska, Unia Europejska oraz Sojusz Północnoatlantycki. Podobnie jak przypadku Szwecji Finlandia prowadzi politykę niezaangażowania przy jednoczesnym aktywnym uczestnictwie w kreowaniu unijnych polityk, $w$ tym Wspólnej Europejskiej Polityki Bezpieczeństwa i Obrony. Ważną rolę odgrywa w niej także kooperacja z pozostałymi krajami nordyckimi i Republiką Federalną Niemiec oraz utrzymywanie ścisłej współpracy z Sojuszem Północnoatlantyckim. Finlandia koncentruje się na stabilizowaniu regionalnej sytuacji politycznej oraz

49 Propozycja złożona w grudniu 2010 r. ówczesnemu federalnemu ministrowi obrony Karlowi-Theodorowi zu Gutenbergowi dotyczyła nawiązania ścisłej współpracy w ramach Europejskiej Polityki Bezpieczeństwa i Obrony. 
prowadzeniu regionalnej polityki eksploatacji zasobów naturalnych ${ }^{50}$. Jej polityka uwzględnia również konsekwencje regionalnych przeobrażeń polityczno-społecznych z udziałem Rosji, a zwłaszcza ewentualnego konfliktu tego państwa z państwami bałtyckimi, a także skutki społeczne wewnętrznych wydarzeń w tym państwie lub awarii technicznych, w tym głównie jądrowych lub znacznych klęsk żywiołowych ${ }^{51}$. Tak zdefiniowane zagrożenia powodują, że celem polityki bezpieczeństwa jest przede wszystkim zapewnienie bezpieczeństwa ekologicznego oraz żeglugi na akwenach bałtyckich, zwłaszcza w Zatoce Botnickiej i Fińskiej, obrony terytorium kraju przed atakiem zbrojnym oraz konsekwencjami wewnętrznych wydarzeń w Rosji. Zdecydowanym priorytetem pozostaje zapewnienie bezpieczeństwa morskiego, a podejmowane przedsięwzięcia skoncentrowane zostały na zapewnieniu bezpieczeństwa żeglugi, zwłaszcza w odniesieniu do zagrożeń wynikających z rozlewów olejowych i prowadzenia żeglugi na akwenach zalodzonych, minimalizowaniu ekologicznych konsekwencji wykorzystania akwenu Morza Bałtyckiego i eksploatacji jego zasobów. Podstawą aktywności jest szeroko rozbudowany system monitoringu akwenów morskich, jednak siły morskie traktowane są jako ważny komponent służący do realizacji zakładanych celów.

Republiki bałtyckie za gwarancję bezpieczeństwa narodowego uznają członkostwo w NATO i Unii Europejskiej oraz podkreślanie swojej suwerenności ${ }^{52}$. Przejawem tak pojmowanej niezależności jest stosunek do mniejszości narodowych tworzących istotną pod względem liczebności grupę społeczną. Polityka ta stanowi problem w wymiarze wewnętrznym oraz w stosunkach $\mathrm{z}$ sąsiadami, zwłaszcza Rosją ${ }^{53}$. Istotną rolę w polityce bezpieczeństwa odgrywają także kwestie gospodarcze, szczególnie konsekwencje wymiany handlowej z Federacją Rosyjską. Dzięki tranzytowi stanowi ona istotne źródło dochodów, jednak prowadzi także do zwiększenia udziału rosyjskich przedsiębiorstw na rynku wewnętrznym i przejmowania przez firmy rosyjskie narodowych podmiotów gospodarczych i finansowych. Znaczenie wymiany handlowej i tranzytowej roli państw bałtyckich oraz spore uzależnienie ich sektora finansowego od Rosji staje się jednym z poważniejszych zagrożeń ich bezpieczeństwa. Zagrożenie rosyjskie postrzegane jest także w kontekście funkcjonowania na obszarze tych państw mniejszości rosyjskojęzycznej, której liczbę szacuje się na

50 Zob. Omówienie wystapienia Ministra Spraw Zagranicznych Finlandii dr Erkki Tuomioji wygłoszone podczas Konferencji „Empowering Euro-Atlantic Security: New Challenges, Threats and Opportunities” $z 17$ X 2011 r.w Helsinkach, s. 2-3, http://www.sea.org.pl/sites/default/files/Omowienie_wyst_Ministra_Tuomioja.pdf.

51 T. Ries, Finland and NATO, www. mil.fi/perustietoa/julkaisut/finland_and_NATO/chapter_1/dsp.

52 Jest ona definiowana jako supremacja władzy państwowej nad wszelkimi normami wewnętrznymi w państwie gwarantująca państwu całkowitą swobodę w prowadzeniu polityki zagranicznej.

53 Za przykłady mogą tu służyć zamieszki ludności rosyjskojęzycznej i protest Rosji powodowane usunięciem symbolicznego pomnika „Żołnierza z brązu” z centrum Tallina oraz protesty polskiej mniejszości spowodowane zmianami systemu kształcenia na Litwie. 
29-34\%. Konsekwentna polityka przymusowej asymilacji lub wykluczenia społecznego powodowała zarówno protesty społeczne, jak i reakcje rosyjskie ${ }^{54}$.

Czynniki te powodują, że kraje bałtyckie zdecydowanie opierają swoje gwarancje bezpieczeństwa w wymiarze polityczno-militarnym na fakcie członkostwa w Pakcie Północnoatlantyckim ${ }^{55} \mathrm{i}$ wzajemnej współpracy. Kooperacja ta ogranicza się jednak wyłącznie do prezentowania wspólnego stanowiska na forum NATO i UE ${ }^{56}$. W niewielkim stopniu w narodowych strategiach bezpieczeństwa państwa te uwzględniają także rolę Wspólnej Polityki Bezpieczeństwa i Obrony ${ }^{57}$. Swoje działania w ramach unijnych polityk koncentrują na skierowanych do regionu politykach szczegółowych, a zwłaszcza polityce morskiej i Strategii UE dla Morza Bałtyckiego. Wynika to przede wszystkim z faktu traktowania przez UE sporów granicznych z Rosją jako problemu stosunków bilateralnych Łotwy, Litwy i Estonii. Stanowisko to spowodowało, że poszczególne republiki bałtyckie zdecydowały się na poszerzenie swojej polityki bezpieczeństwa przez podjęcie współpracy z państwami regionu. Litwa skoncentrowała się na kooperacji z dwoma najważniejszymi partnerami gospodarczymi, czyli RFN i Polską. Estonia zdecydowała się na intensyfikację współpracy w ramach $\mathrm{NATO}^{58}$

${ }^{54}$ Wskazać tu można ponownie przykład protestów po usunięciu tallińskiego pomnika „Żołnierza z brązu”, a zwłaszcza aktywność organizacji „Nocna Straż” lub rosyjskie decyzje zerwania umów granicznych czy wprowadzenia ruchu bezwizowego dla rosyjskojęzycznej.

55 NATO od 2004 roku zapewnia bezpieczeństwo przestrzeni powietrznej Bałtów w ramach misji Baltic Air Policing, a w grudniu 2010 roku ujawniono, że Sojusz posiada operacyjne plany podjęcia działań zbrojnych w przypadku pogwałcenia suwerenności Litwy, Łotwy i Estonii. W tym kontekście postrzegać należy także umiejscowienie w tych państwach siedzib struktur Paktu, w tym Centrum Doskonalenia Obrony przed Cyberatakami (Tallin) oraz wybór Rygi na miejsce szczytu Paktu w 2006 roku.

56 Ministrowie obrony Litwy, Łotwy i Estonii formalnie co dwa lata odbywają wspólne posiedzenia, w trakcie których decydują o formie kooperacji. Określone 2 grudnia 2011 r. formy współpracy wojskowej ograniczyły się do decyzji o budowie wspólnego komponentu Sił Odpowiedzi NATO i podjęcia kooperacji na wzór rozwiązań nordyckich (zwłaszcza wspólnej budowy poszczególnych komponentów sił zbrojnych).

57 Zob. R. Vilpisauskas, Baltic States Membership in the WEU and NATO: Links, Problems and Perspectives, Vilnius 2000.

$58 \mathrm{~W}$ ramach NATO Estonia, poza utrzymaniem zasady kolektywnej obrony, próbuje zapewnić sobie bezpieczeństwo terrorystyczne i energetyczne oraz bezpieczeństwo regionalnego systemu transportowego. Ze względu na charakter gospodarki i wysoki poziom cybernetyzacji państwa równie ważną co zasada zbiorowej obrony w ramach NATO rolę odgrywają ponadnarodowe koncepcje przeciwdziałania zagrożeniom w postaci szeroko rozumianej przestępczości w przestrzeni. Zasady te określone zostały zarówno w strategii bezpieczeństwa narodowego, jak i strategiach operacyjnych w postaci strategii walki z terroryzmem z 2010 roku oraz strategii bezpieczeństwa energetycznego. W estońskiej polityce bezpieczeństwa, po doświadczeniach $\mathrm{z}$ atakami na państwowe systemy informatyczne, szczególne miejsce przyznano bezpieczeństwu informatycznemu, co podkreśla trzecia ze strategii operacyjnych w sferze bezpieczeństwa. Jest nią, obowiązująca od 2008 r., strategia bezpieczeństwa cybernetycznego. Powstały w oparciu o nią narodowy system ochrony przestrzeni cybernetycznej został w pełni dostosowany do funkcjonowania w ramach posiadającego akredytację 
i podjęcie ściślejszej kooperacji z państwami nordyckimi, a pierwszoplanowym partnerem w tej dziedzinie jest Finlandia. Natomiast Łotwa uznaje, że wystarczające gwarancje bezpieczeństwa zapewni jej stopniowe poszerzanie współpracy w ramach NATO i w sojuszu z USA. Republiki bałtyckie dążą także do tego, by poszczególne polityki wspólnotowe Unii Europejskiej stanowiły minimalne gwarancje bezpieczeństwa o charakterze ekonomiczno-politycznym. Dotyczy to zwłaszcza polityki energetycznej.

\section{5. „Bałtyckie” uwarunkowania kształtu polskiej strategii bezpieczeństwa morskiego}

Przedstawiony zarys narodowych polityk bezpieczeństwa państw regionu oraz skala kooperacji politycznej i gospodarczej na tym obszarze ograniczają możliwość zaistnienia poważnego sporu politycznego. Nie ogranicza to natomiast możliwości powstania sytuacji kryzysogennej, wynikającej z zarzucenia lub ograniczenia przez państwo kooperacji regionalnej i podjęcia polityki osiągania wąsko pojętych interesów narodowych. Dotyczy to zwłaszcza prowadzenia spornych inwestycji bałtyckich czy sposobu wykorzystywania akwenu jako szlaku transportowego. Dlatego też Polska w swojej koncepcji zapewnienia bezpieczeństwa morskiego musi odnosić się do generowanych zagrożeń i potencjalnych obszarów konfliktogennych ${ }^{59}$. Uwarunkowania polityczne, a zwłaszcza charakter stosunków międzynarodowych w zlewisku Bałtyku, powodują, że na jego akwenie możliwe są dwie formy oddziaływania zbrojnego. Pierwszą jest konflikt lokalny, który może przybrać charakter zbrojnych działań przygranicznych, ograniczonej agresji na Polskę (jako konsekwencja jej zaangażowania w rozwiązywanie innego konfliktu poza własnym terytorium) oraz ataku rakietowo-lotniczego na terytorium Polski. Druga forma oddziaływania militarnego może być konsekwencją kryzysu lub konfliktu oddziałującego na państwo sojusznicze i wymagającego reakcji państwa polskiego. Natomiast za mało prawdopodobne, również ze względu na charakterystykę akwenu, uznać należy wystąpienie regionalnego konfliktu międzypaństwowego, w trakcie którego na dużą skalę wykorzystywane byłyby uderzeniowe siły morskie. Niewielki jak na

Paktu systemu Cyber Defence Centre of Excellence, w którym uczestniczą także Niemcy, Słowacja, Włochy, Litwa, Łotwa i Hiszpania, Węgry, a w trakcie negocjacji pozostają USA i Turcja. Szerzej zob. National Security Concept of Estonia, Adopted by the Riigikogu on May 12, 2010. Zakłada on, że bezpieczeństwo cybernetyczne państwa zapewniają sobie w ramach narodowych strategii bezpieczeństwa cybernetycznego.

59 Poza Federacją Rosyjską wszystkie państwa bałtyckie zakładają niskie prawdopodobieństwo wystąpienia międzypaństwowego konfliktu, którego będą stroną, i nadają swoim flotom charakter obronny. W przypadku Rosji doktryna morska przewiduje wykorzystanie Bałtyku jako akwenu o ograniczonej roli w konflikcie militarnym o charakterze regionalnym lub globalnym. Zob. P. Mickiewicz, Morze Battyckie w rosyjskiej... op. cit., s. 149-151. 
potrzeby tych flot akwen i jego głębokość, brak naturalnych zasłon (wyspy, zatoki) w jego części południowej stwarza bowiem ograniczone możliwości użycia dużych okrętów nawodnych i podwodnych. Rozciągłość południkowa i równoleżnikowa tworzą zaś realną możliwość ich skutecznego rażenia bronią rakietową.

Za bardziej prawdopodobne działania w sytuacji konfliktogennej uznać należy zastosowanie przez państwo-agresora form agresji pośredniej przez wywieranie presji politycznej na instytucje państwa lub firmy, próby ograniczania jurysdykcji państwa lub prawa wolności żeglugi, realizację na obszarach morskich projektów oddziałujących na poziom bezpieczeństwa państwa, a przede wszystkim prowadzenie działań o charakterze dywersyjnym. W przypadku zarówno działań podejmowanych przez państwa, jak i rywalizacji formalnych i nieformalnych ugrupowań niepaństwowych za najbardziej prawdopodobne uznać należy wykorzystywanie środków definiowanych jako niemilitarne. Na akwenach morskich koncentrować się one będą na działaniach:

- skierowanych przeciw jednostkom pływającym (statkom, okrętom, jednostkom w służbie państwowej) i obiektom hydrotechnicznym ${ }^{60}$, prowadzonych w sposób typowy dla sił i środków dywersji podwodnej;

- prowadzonych $\mathrm{w}$ formie krótkotrwałego oddziaływania ogniowego na wybrane jednostki pływające i obiekty hydrotechniczne;

- prowadzonych przy użyciu min morskich na morskich szlakach komunikacyjnych i w obszarach okołoportowych;

- ukierunkowanych na zawładnięcie wybranymi jednostkami pływającymi lub obiektami hydrotechnicznymi;

- prowadzonych przez fizyczne oddziaływanie na wybrane jednostki pływające i obiekty hydrotechniczne (taranowanie, przerywanie rurociągów i kabli podwodnych itp.).

Zaprezentowana charakterystyka zagrożeń na polskich akwenach morskich pozwala na uznanie za podstawowy instrument systemu ochrony interesów państwa Zautomatyzowanego Systemu Radarowego Nadzoru, ale po poszerzeniu jego możliwości monitorowania polskich obszarów morskich. Powinien on zapewnić monitoring sytuacji nawodnej przynajmniej na morzu terytorialnym i w Strefie Wyłączności Ekonomicznej oraz przepływ uzyskanych informacji w czasie rzeczywistym do służb operacyjnych. Uzyskiwane $\mathrm{z}$ tego zobrazowania informacje nie mogą ograniczać się do zapewnienia możliwości ochrony granicy i strefy EEZ, lecz powinny być także pomocne we wspomaganiu procesu decyzyjnego na szczeblu operacyjnym. Dotyczy to zwłaszcza uzyskania dowolnych informacji na temat samej jednostki prowadzącej żeglugę, charakteru prowadzonej żeglugi oraz podstawowych informacji nawigacyjnych. Słuszne jest także użycie tego systemu jako instrumentu

60 Platformy wydobywcze, wydobywczo-magazynowe, magazynowe, badawcze, pławy przeładunkowe, stałe i pływające oznakowanie nawigacyjne. 
pozwalającego na przygotowanie wariantowych planów użycia sił własnych na akwenach morskich. Powinien być on wykorzystywany do prowadzenia przez służbę operacyjną bieżących analiz czasu dojścia w rejon działań przy uwzględnieniu aktualnych i przewidywanych warunków pogodowych, wyznaczenia linii dozoru w zależności od sposobu prowadzenia żeglugi przez jednostki w polskich obszarach morskich, czasu osiągnięcia tych linii dozoru, możliwości dokonania przez nie rozpoznania. Zasadne byłoby wykorzystywanie tego systemu jako instrumentarium wspierającego kierowanie akcją prowadzoną we współpracy z innymi służbami odpowiadającymi za poziom bezpieczeństwa na polskich akwenach morskich, zwłaszcza z urzędami morskimi i Marynarką Wojenną RP.

Ze względu na znaczenie pominiętej w niniejszym opracowaniu skali zagrożeń związanych z bałtycką przestępczością zorganizowaną, zasadne jest także wykorzystanie tego systemu do jej zwalczania. Tym bardziej że wymogi techniczne pozwolą na monitorowanie akwenu pod kątem potencjalnych działań dywersyjnych. Tym samym Zautomatyzowany System Radarowego Nadzoru powinien mieć możliwości technicznej obserwacji obszarów morskich w dwóch wariantach. W wariancie przybrzeżnym - do odległości 3 mil morskich, a najlepiej do izobaty $9 \mathrm{~m}$ - powinien być zdolny do wykrycia i prowadzenia obserwacji małych jednostek. Charakterystyka techniczna jednostek operujących w tym akwenie powoduje, że radary powinny wykryć obiekt posiadający tzw. skuteczną powierzchnię odbicia nie mniejszą niż $1,5 \mathrm{~m}^{2}$. Natomiast w obszarach granicznych wód terytorialnych i Strefie Wyłączności Ekonomicznej powierzchnia skutecznego odbicia powinna wynosić około 120 do $150 \mathrm{~m}^{2}$. Zasadne jest także uzyskanie przez system zobrazowania statków powietrznych na niskiej wysokości (do $300 \mathrm{~m}$ ), lecz wymóg ten powinien dotyczyć raczej wód terytorialnych.

Skuteczność funkcjonowania systemu wymaga także posiadania sił okrętowych mogących podjąć efektywne działania na podstawie danych uzyskanych z ZSRN. Dotyczy to zwłaszcza promienia działania, czyli odległości operowania w oddaleniu od portu, dzielności morskiej, zezwalającej na operowanie w trakcie niesprzyjających warunków pogodowych, oraz prowadzenia działań na akwenach płytkowodnych. Uwarunkowania hydrologiczne Bałtyku w zestawieniu z formami prowadzenia żeglugi i rodzajami jednostek uprawiających żeglugę uzasadniają konieczność wyposażenia sił Straży Granicznej w jednostki pełnomorskie, przybrzeżne i prowadzące kontrolę na akwenach płytkowodnych. Pełnomorskie jednostki patrolowe muszą być gotowe do podjęcia działań w Strefie Wyłączności Ekonomicznej i w każdych warunkach pogodowych. Zasadne jest, by posiadały nieograniczoną dzielność morską, co przekłada się na cechy techniczne. W warunkach Bałtyku Południowego powinny one mieć długość powyżej $40 \mathrm{~m}$, wyporność powyżej 500 BRT. Zasięg ich pływania to maksymalnie 3000 mil morskich, a wyposażenie i uzbrojenie powinny zapewnić możliwość ich wykorzystania do przeprowadzenia i zabezpieczenia inspekcji na 
pokładzie statku handlowego. Za wystarczające uzbrojenie takiej jednostki należy uznać armatę średniego kalibru ze stacją radiolokacyjną, stanowiska dla karabinów maszynowych oraz granatników automatycznych na podstawach morskich. W polskich warunkach nie ma uzasadnienia dla wyposażenia takich jednostek w pokład umożliwiający lądowanie śmigłowca, lecz muszą być one wyposażone w sprzęt pozwalający na taktyczną współpracę ze śmigłowcem w trakcie ewentualnej akcji abordażowej i podczas prowadzenia kontroli. Rozważyć należy, ze względu na posiadaną prędkość marszową (około 20 węzłów), wyposażenie jednostki w łódź pościgową zdolną do osiągania prędkości powyżej 30 węzłów, w skład której wchodziłaby kilkuosobowa (do 5 osób) uzbrojona załoga. Należy też wziąć pod uwagę, zwłaszcza w kontekście konieczności zwalczania działań o charakterze dywersyjnym czy wręcz terrorystycznym, wariantowe jej wyposażenie w urządzenia umożliwiające poszukiwanie i wykrywanie sił i środków dywersji podwodnej oraz stanowisk lekkich kierowanych pocisków rakietowych.

Powierzchnia polskiej Strefy Wyłączności Ekonomicznej, jej rozległość fizyczna, charakter prowadzonej żeglugi i eksploatacji zasobów oraz możliwości systemów monitorowania powodują, że uzasadnione jest utrzymywanie w gotowości do podjęcia działań minimum trzech jednostek tego typu. Uznać więc należy, że w składzie Morskiego Oddziału Straży Granicznej powinno funkcjonować ich minimum sześć. Wskazać trzeba również na konieczność wzmocnienia możliwości efektywnego patrolowania akwenów wzdłuż Pomorza Środkowego i skrócenia czasu dotarcia do najbardziej na północ wysuniętych obszarów polskiej EEZ. Zasadne więc wydaje się także przygotowanie wariantowego rozwiązania, zezwalającego na prowadzenie działań patrolowych w środkowej części polskiej EEZ przez dwie jednostki. Tym samym ich liczba wzrosłaby do czterech, a dodatkowo konieczne staje się przygotowanie dla nich stosownej bazy w oparciu o port w Darłowie lub Kołobrzegu.

Kontrola akwenów przybrzeżnych prowadzona jest $\mathrm{z}$ reguły przez jednostki określane jako inspekcyjno-pościgowe. Swoją działalność mogą one prowadzić w oparciu o porty polskiego wybrzeża i w rejonach koncentracji jednostek prowadzących działalność gospodarczą na morzu. Funkcję baz wykorzystywanych przez te jednostki mogą z powodzeniem pełnić porty w Nowym Porcie i na Helu, we Władysławowie, w Łebie, Ustce, Darłówku, Kołobrzegu, Dziwnowie i Świnoujściu. Zaprezentowane rozmieszczenie sił określa także ich liczbę na dziewięć jednostek prowadzących działania, co wprost przekłada się na konieczność posiadana w sumie od 15 do 18 sztuk. Przewidywany dla nich akwen działania pozwala na uznanie, że mogą mieć ograniczone w stosunku do jednostek pełnomorskich cechy techniczne. W warunkach polskich ich wyporność nie musi przekraczać 200 BRT, a długość 30 $\mathrm{m}$, co pozwoli na zachowanie dzielności morskiej do stanu morza 4. Wymogiem jest zanurzenie maksymalnie na głębokość $2 \mathrm{~m}$ oraz specyficznie zbudowany układ napędowy. Jednostki te mogą posiadać stosunkowo niewielką prędkość marszową, 
wynoszącą około 8 węzłów ${ }^{61}$, i stosować ją w trakcie patrolu. Równocześnie, ze względu na konieczność podjęcia akcji wobec statku handlowego, którego prędkość marszowa $\mathrm{z}$ reguły przekracza 17 węzłów, lub jednostki sportowej, muszą mieć możliwość stosowania prędkości pościgowej wynoszącej od 32 do 40 węzłów. Ich uzbrojenie stanowić powinna jedna armata o powszechnie stosowanym w państwach europejskich kalibrze $40 \mathrm{~mm}$. Rozważyć można także przygotowanie rozwiązań pozwalających na wariantowe doposażenie jednostek w lekkie wyrzutnie pocisków rakietowych oraz podkilowe stacje hydroakustyczne, zezwalające na wykrycie środków dywersji podwodnej.

Szczególne znacznie przypisać należy jednostkom prowadzącym działania na akwenach płytkowodnych. Obowiązek ochrony zewnętrznej granicy UE i Strefy Schengen oraz dominacja tzw. rosyjskojęzycznych grup przestępczych w strukturze regionalnej przestępczości zorganizowanej powoduje, że akwen ten musi znajdować się pod pełną kontrolą polskich służ granicznych. Istotnym determinantem określającym sposób reakcji na zdarzenia uznane za przestępcze w tym akwenie jest jego zamarzanie, a także ukształtowanie pasa przybrzeżnego. Czynniki te powodują, że do patrolowania tego akwenu wykorzystywane powinny być małe kutry patrolowe i poduszkowce posiadające zdolność do pływania po akwenach portowych, redach, kotwicowiskach oraz wodach zalewowych i zatokowych. Ze względu na występujące zalodzenie efektywnym rozwiązaniem jest wykorzystanie właśnie poduszkowców zdolnych do poruszania się po wodzie lub zalodzonym akwenie z prędkością dorównującą motorowym łodziom półsztywnym (około 30 węzłów), mających możliwość zabrania na pokład grupy kontrolno-inspekcyjnej lub pościgowej i posiadających zdolność do poruszania się po plażach, rejonach bagnistych czy porośniętych sitowiem z prędkościami pozwalającymi na zatrzymanie uciekinierów (maksimum $30 \mathrm{~km} / \mathrm{h}$, czyli do 16 węzłów). Niemniej jednak obok poduszkowców powinny być wykorzystywane małe kutry patrolowe o wyporności około 30 ton i dysponujące prędkością około 25 węzłów. Za wystarczające uzbrojenie uznać należy wielkokalibrowy karabin maszynowy. Wymogiem zarówno w odniesieniu do kutrów, jak i poduszkowców jest możliwość ich wykorzystania w warunkach nocnych i ograniczonej widoczności, muszą mieć także zdolności do holowania zatrzymanych jednostek (o ciężarze do około 2,5-3 ton). Promień działania tego typu jednostek $\mathrm{w}$ warunkach polskich może wynosić 20 mil morskich, a czas przebywania $\mathrm{w}$ rejonie to maksimum pół doby. Zasadne jest, aby jednostka taka posiadała zdolność pokonywania przeszkód do wysokości maksymalnej od 0,5 do 0,8 ma (standardowa wysokość przeszkód wodnych, pomostów rybackich itp.). Specyfika wykorzystania

${ }^{61}$ Standardowa prędkość jednostek rybackich w trakcie połowu to 4 węzły, a prędkość marszowa to właśnie około 8 węzłów. Zaś jachty żaglowe i turystyczne jednostki motorowe w normalnej eksploatacji też rzadko przekraczają te prędkości. 
wymaga, by na pokładzie mógł być transportowany lądowy sprzęt pościgowy (quad lub inny pojazd jednośladowy).

Głównymi akwenami działań małych jednostek patrolowych będą wody Zalewu Wiślanego oraz Szczecińskiego oraz - w mniejszym stopniu - Zatoki Gdańskiej i Puckiej. Na akwenie Zalewu Wiślanego zasadne jest utrzymanie minimum dwóch poduszkowców i dwóch kutrów patrolowych, co wynika z konieczności zapewnienia ochrony granicy zewnętrznej UE. Natomiast na akwenie Zatoki Gdańskiej minimum czterech kutrów patrolowych, a w Zalewie Szczecińskim i rejonie Szczecin-Świnoujście kolejnych sześciu kutrów patrolowych i przynajmniej dwóch poduszkowców. W sumie liczba angażowanych w bieżące działania jednostek to dwanaście kutrów patrolowych i sześć poduszkowców.

Pomimo ustawowego nałożenia obowiązku ochrony przestrzeni powietrznej przez siły Ministerstwa Obrony Narodowej zasadne jest wyposażanie Straży Granicznej w specjalistyczne statki powietrzne przeznaczone do sprawowania nadzoru i prowadzenia patroli nad polskimi akwenami morskimi, do realizacji działań rozpoznawczych, także w zakresie zwalczania nielegalnej eksploracji zasobów żywych w polskiej EEZ i skażenia środowiska morskiego przez uczestników żeglugi oraz współuczestniczenia $\mathrm{w}$ ewentualnych akcjach ratowniczych. Statki powietrzne powinny być również zdolne do prowadzenia usług transportowych na potrzeby działań operacyjnych. Zakres zadań powoduje, że ich prędkość przelotowa powinna zezwalać na skuteczny monitoring środkami technicznymi ${ }^{62}$, czyli wynosić około 300 $\mathrm{km} / \mathrm{h}$. Zasięg lotu i czas przebywania w powietrzu uzależniony jest zaś od wielkości akwenu. W polskich warunkach zasięg powinien wynosić około $1500 \mathrm{~km}$, a czas przebywania w powietrzu to 5-6 godzin.

\section{Podsumowanie}

Europa bałtycka to region o dużym poziomie stabilizacji politycznej i takim samym zakresie kooperacji gospodarczej. W narodowych politykach bezpieczeństwa państw regionu dominuje przekonanie o niewielkim zagrożeniu o charakterze konfliktu zbrojnego. Nie oznacza to braku poczucia zagrożenia, ale wynika ono głównie z rozbieżnych interesów państw bałtyckich, ulokowanych lub powiązanych z wykorzystaniem akwenu Morza Bałtyckiego. Potencjalne zagrożenia bezpieczeństwa to przede wszystkim zdarzenia wywoływane intencjonalnie przez

\footnotetext{
62 Podstawowe wyposażenie techniczne to radar posiadający możliwości wykrywania obiektów na morzu i lądzie oraz zanieczyszczeń na akwenach morskich (plam olejowych). Radar powinien być sprzężony ze specjalistycznym skanerem na promieniowanie podczerwone i ultrafioletowe, kamerą telewizyjną oraz aparatem fotograficznym zapewniającym zebranie materiałów dowodowych, noktowizorem umożliwiającym prowadzenie obserwacji i rozpoznanie obiektów w warunkach ograniczonej widzialności oraz reflektorem poszukiwawczym (szperaczem).
} 
aktorów sceny międzynarodowej i w dużej mierze odnoszące się do zakłócenia możliwości prowadzenia żeglugi lub eksploatacji morza (akty dywersji kierowane przeciwko obiektom i budowlom morskim, blokady portów itp.). Innym rodzajem zagrożeń, ale niemających charakteru zagrożeń politycznych, jest działalność przestępcza w postaci nielegalnej eksploatacji zasobów morza, przemytu towarowego oraz - w mniejszym stopniu - zjawiska o charakterze aktów piractwa lub terroru i nielegalnego przemytu osób. Czynniki te powodują, że koncepcje wykorzystania sił morskich państw regionu mają charakter defensywny, ukierunkowany na ochronę własnych interesów politycznych i gospodarczych. Z tego powodu bardzo ważnym elementem budowy militarnego potencjału morskiego jest uwzględnienie geograficznych uwarunkowań ochrony akwenów morskich. Doskonale kwestię tę prezentują rozwiązania stosowane przez RFN i kraje nordyckie. Państwo niemieckie posiada system rozpoznania morskiego pozwalający na monitorowanie sytuacji na akwenie Zatoki Meklemburskiej oraz właściwą dyslokację sił przeznaczonych do obrony akwenów morskich i skutecznego zwalczania pojawiających się na nich zagrożeń bezpieczeństwa. Skandynawowie natomiast doskonale dostosowali narodowe plany obrony do charakterystyki wybrzeża, a ze względu na znaczenie kwestii skażeń akwenów morskich doprowadzili do powstania ogólnobałtyckiego systemu ich ochrony. Odnosząc te dywagacje do problemu polskiej polityki bezpieczeństwa morskiego, należy stwierdzić, że polska strategia bezpieczeństwa morskiego powinna się koncentrować na zapewnieniu pełnej realizacji interesów morskich państwa przy uwzględnieniu regionalnego kontekstu polityczno-gospodarczego oraz poziomu regionalnego oddziaływania systemu międzynarodowego. Nie może być ona prostą kompilacją strategii państw bałtyckich lub - co stanowi największe zagrożenie dla jej istoty - prostą wizją wykorzystania gospodarki morskiej w polityce państwa czy koncepcji obrony terytorium kraju przed potencjalnym militarnym atakiem wyprowadzonym od strony morza. Powinna uwzględniać aktywną ochronę swoich interesów na akwenie bałtyckim, zwłaszcza sposobów wykorzystania akwenów morskich. Odnosić się musi natomiast do form zapewnienia jurysdykcji i kontroli własnych akwenów morskich i określonego poziomu bezpieczeństwa w obszarach geograficznych i funkcjonalnych umiejscowienia polskich interesów morskich.

Dokonując w tym kontekście oceny założeń strategii bezpieczeństwa, a zwłaszcza Strategii Rozwoju Systemu Bezpieczeństwa RP do 2022 roku, należy uznać, że trafnie zdefiniowano rodzaj możliwych zagrożeń bezpieczeństwa morskiego państwa. Niestety mimo właściwego wskazania spectrum możliwych zagrożeń, cechą polskich rozwiązań jest brak korelacji koncepcji ochrony interesów państwa na morzu z planami rozwojowymi zarówno poszczególnych segmentów systemu bezpieczeństwa morskiego, jak i sfer gospodarki państwa wykorzystujących akweny morskie. Sztandarowym przykładem jest brak korelacji polityki energetycznej państwa z koncepcjami rozwoju Marynarki Wojennej i Morskiego Oddziału Straży 
Granicznej. Budowa terminalu gazowego wymaga przygotowania systemu ochrony lub wręcz konwojowania zbiornikowców w sytuacji kryzysogennej. Odnosząc się do potencjalnych zagrożeń pozamilitarnych, wskazać należy niedostosowanie do zagrożenia w postaci katastrofalnego rozlewu olejowego. Polska, będąc państwem o dużym poziomie zagrożenia, nie zbudowała w pełni skorelowanego ze sobą systemu przeciwdziałania zagrożeniom ekologicznym (system monitoringu skażeń, prawne regulacje dotyczące zasad transportu ładunków niebezpiecznych) i zagrożeniom militarnym (niedostosowanie taktycznej charakterystyki okrętów i uzbrojenia brzegowego Marynarki Wojennej RP do rodzajów zagrożeń i prawdopodobnych form ataku oraz fiasko planów modernizacyjnych tego rodzaju sił zbrojnych). Natomiast jako stosunkowo dobry ocenić należy poziom przygotowania sił Straży Granicznej do zwalczania wybranych zagrożeń pozamilitarnych (nielegalna imigracja, przemyt).

\section{LITERATURA:}

Dokumenty

1. BRISK - Sub-regional risk of spill of oil and hazardous substances in the Baltic Sea, http://www.brisk.helcom.fi

2. Стратегия национальной безопасности Российской Федеращии до 2020 года, УТВЕРЖДЕНА Указом Президента Российской Федерации от 12 мая 2009 г. № 537.

3. Distribution of export and import of the Russian Federation by some foreign countries, Federal State Statistic Service, Russian Federation.

4. Енергетиетическая стратегийа России на период до 2030 г.

5. Морская доктрина Российской Федерации на период до 2020 года УТВЕРЖДАЮ Президент Российской Федерации В.Путин 27 июля 2001 г. Пр-1387, p. 3-10.

6. National Security Concept of Estonia, Adopted by the Riigikogu on May 12, 2010.

7. Omówienie wystąpienia Ministra Spraw Zagranicznych Finlandii dr Erkki Tuomioji wygłoszone podczas konferencji Empowering Euro-Atlantic Security: New Challenges, Threats and Opportunities z 17 października 2011 r. w Helsinkach.

8. Russian Federation, Transport Strategy until 2020. Reviewed by the meeting of the State Council of the Russian Federation on October 29, 2003, s. 22 i 29.

9. Указ Президента Российской Федерации „О Военной доктрине Российской Федерации" от 5 февраля 2010 г. N 146.

10. Weißbuch 2006 zur Sicherheitspolitik Deutschlands und zur Zukunft der Bundeswehr, Bundesministerium der Verteidigung, Berlin 2006.

\section{Opracowania}

1. J. Mannhardt, Der Maritime Beitrag im Aufgabenspektrum der Bundeswehr. Konzeptionelle Vorstellungen, Fähigkeiten und Perspektiven, „Soldat und Technik”, 2004, Nr 4. 
2. P. Mickiewicz, Bezpieczeństwo energetyczne i ekologiczne Polski a rozbudowa bałtyckiego systemu transportu surowców energetycznych, [w:] „Rocznik Bezpieczeństwa Międzynarodowego" 2009/2010, Wrocław 2010.

3. P. Mickiewicz, Morze Bałtyckie w polskiej strategii bezpieczeństwa morskiego, Wrocław 2012.

4. P. Mickiewicz, Morze Bałtyckie w rosyjskiej polityce zagranicznej i strategii morskiej, „Rocznik Integracji Europejskiej”, nr 7 (2013).

5. P. Mickiewicz, Uwarunkowania polityczne, gospodarcze i obronne strategii bezpieczeństwa morskiego Rzeczypospolitej Polskiej, [w:] Strategia bezpieczeństwa narodowego Polski, red. J. Gryz, Warszawa 2013.

6. O. Osica, M.A. Сichocкi, Konsolidacja czy dezintegracja? Bezpieczeństwo w subregionie Morza Bałtyckiego, „Nowa Europa”, numer specjalny 2009.

7. T. RiEs, Finland and NATO.

8. „Rocznik Statystyczny Gospodarki Morskiej 2012”, Główny Urząd Statystyczny i Urząd Statystyczny w Szczecinie, Szczecin 2011.

9. K. RokocińsKi, Zagrożenia asymetryczne w regionie Morza Bałtyckiego, Warszawa 2006.

10. D. Rossa-Kilian, Region Morza Bałtyckiego obszarem rozwoju i współpracy. W świetle dokumentów, Toruń 2006.

11. T. Stoltenberg, Nordic Cooperation on Foreign and Security Policy, Proposals presented to the extraordinary meeting of Nordic foreign ministers in Oslo on 9 February 2009.

12. R. Vilpisauskas, Baltic States Membership in the WEU and NATO: Links, Problems and Perspectives, Vilnius 2000.

\title{
THE BALTIC SEA REGION IN THE MARITIME STRATEGIES AND NATIO- NAL SECURITY POLICIES OF ITS COUNTRIES. THE IMPLICATION FOR MARITIME SECURITY OF POLAND
}

\begin{abstract}
The Baltic sea region is considered to be an area of political stability with rather small probability of an armed conflict. However, this doesn't mean that the economic and political rivalry isn't creating particular dangers for the regional security, as is discussed by the author. Dangers arise from the particular maritime policies of the countries involved. The counteractions against possible dangers involve above all the politico-economical actions using the military sea power to guarantee and protect the country's interests. As it is stated in this article, such an approach toward the essence of sea security should also determine the Poland's conception of its sea interests. And based on that, the organizational system and its functions should be applied to strengthen security of the Polish seas. Keywords: Baltic sea, state security, socio-economical security, maritime policy
\end{abstract}

